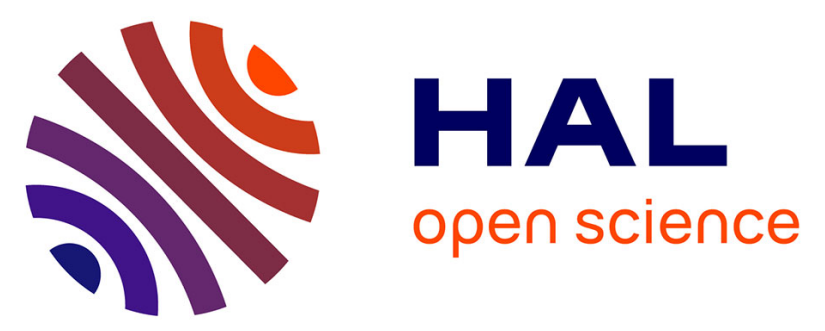

\title{
Synthesis of estrogens in progenitor cells of adult fish brain: Evolutive novelty or exaggeration of a more general mechanism implicating estrogens in neurogenesis?
}

Karen Mouriec, Elisabeth Pellegrini, Isabelle Anglade, Arnaud Menuet, Fátima Adrio, Marie-Lise Thieulant, Farzad Pakdel, Olivier Kah

\section{To cite this version:}

Karen Mouriec, Elisabeth Pellegrini, Isabelle Anglade, Arnaud Menuet, Fátima Adrio, et al.. Synthesis of estrogens in progenitor cells of adult fish brain: Evolutive novelty or exaggeration of a more general mechanism implicating estrogens in neurogenesis?. Brain Research Bulletin, 2008, 75 (2-4), pp.274-80. 10.1016/j.brainresbull.2007.10.030 . hal-00266593

\section{HAL Id: hal-00266593 https://hal.science/hal-00266593}

Submitted on 5 Mar 2010

HAL is a multi-disciplinary open access archive for the deposit and dissemination of scientific research documents, whether they are published or not. The documents may come from teaching and research institutions in France or abroad, or from public or private research centers.
L'archive ouverte pluridisciplinaire $\mathbf{H A L}$, est destinée au dépôt et à la diffusion de documents scientifiques de niveau recherche, publiés ou non, émanant des établissements d'enseignement et de recherche français ou étrangers, des laboratoires publics ou privés. 
Synthesis of estrogens in progenitor cells of adult fish brain: Evolutive novelty or exaggeration of a more general mechanism implicating estrogens in neurogenesis?

K. Mouriec, E. Pellegrini, I. Anglade, A. Menuet, F. Adrio, M.L. Thieulant, F. Pakdel, O. Kah

Running title

Estrogens and neurogenesis in fish

$\underline{\text { Address for correspondence: }}$

Olivier Kah

Neurogenesis and Estrogens

UMR CNRS 6026,

Université de Rennes 1,

Campus de Beaulieu, 35042 Rennes Cedex,

France.

Email: olivier.kah@univ-rennes1.fr

Phone : +33-2 23236765

Fax : +33-2 23236794 


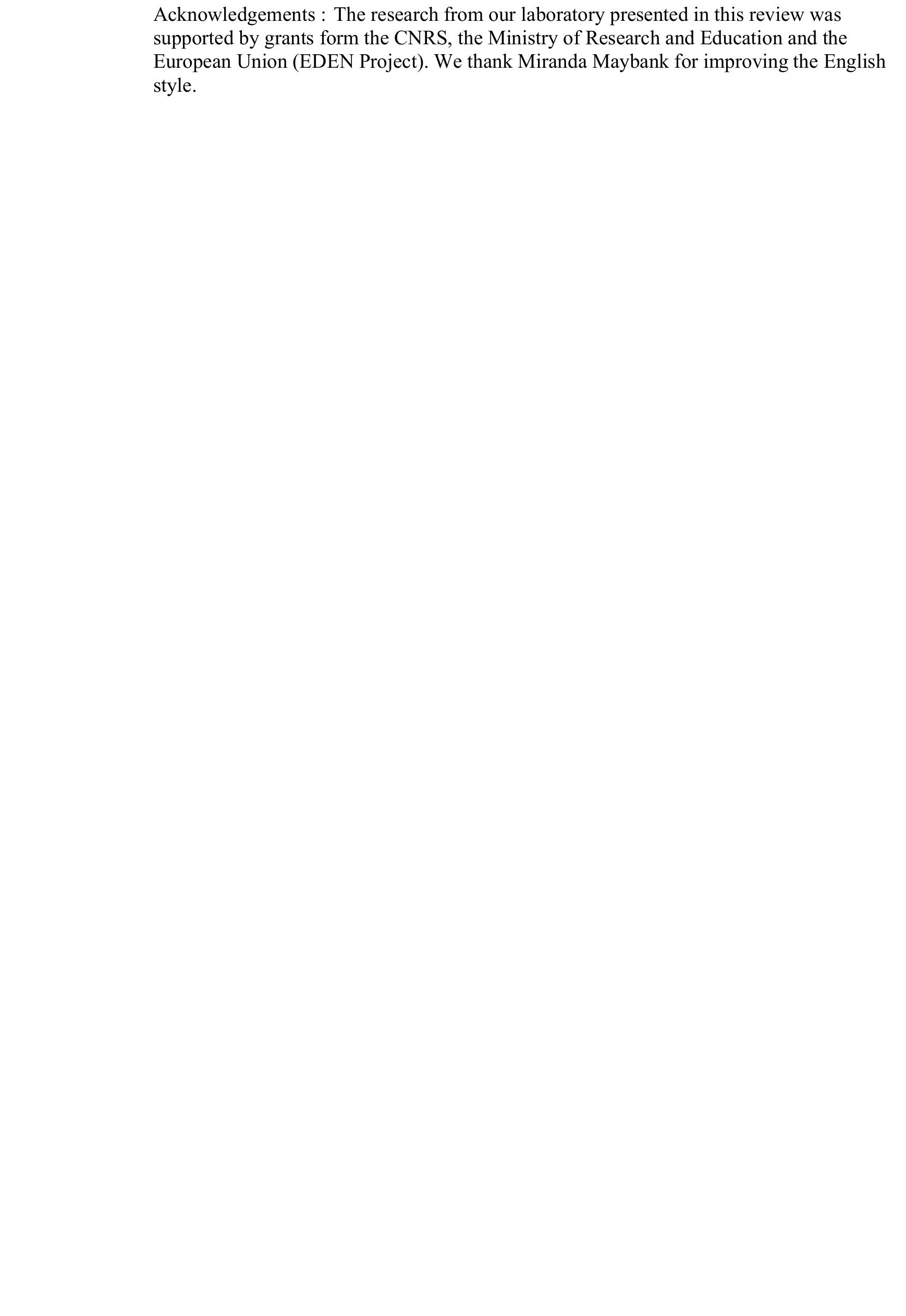

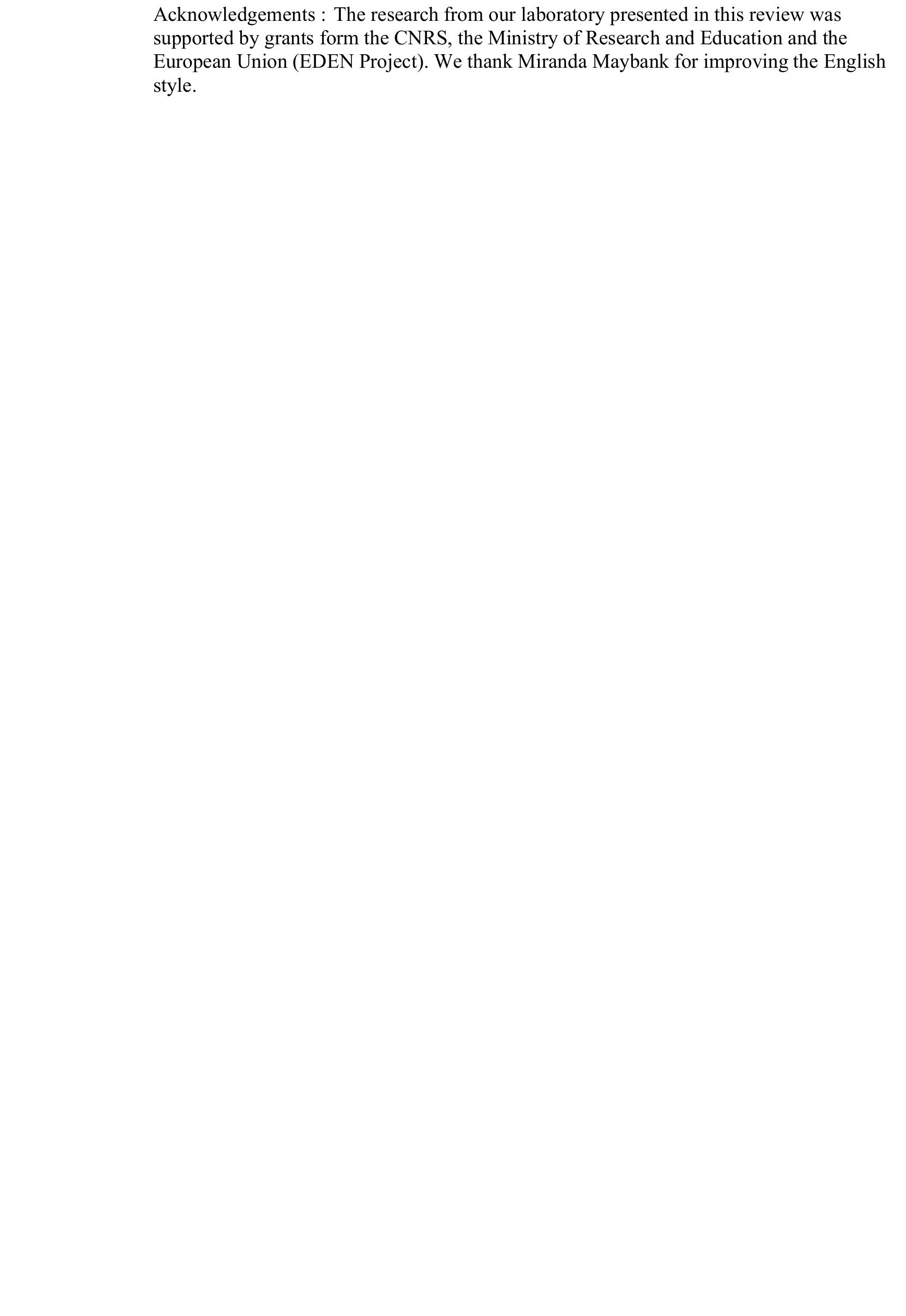

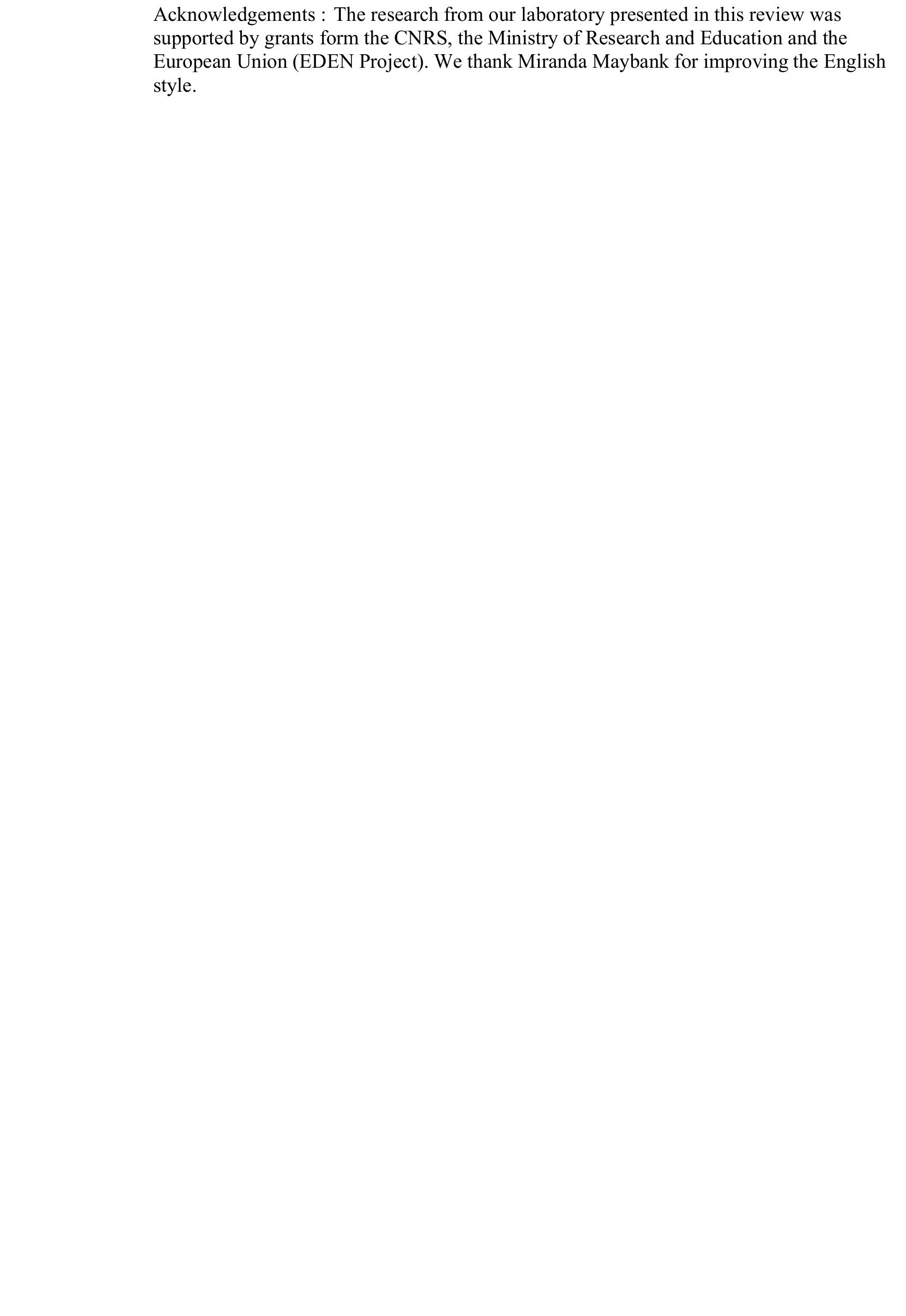

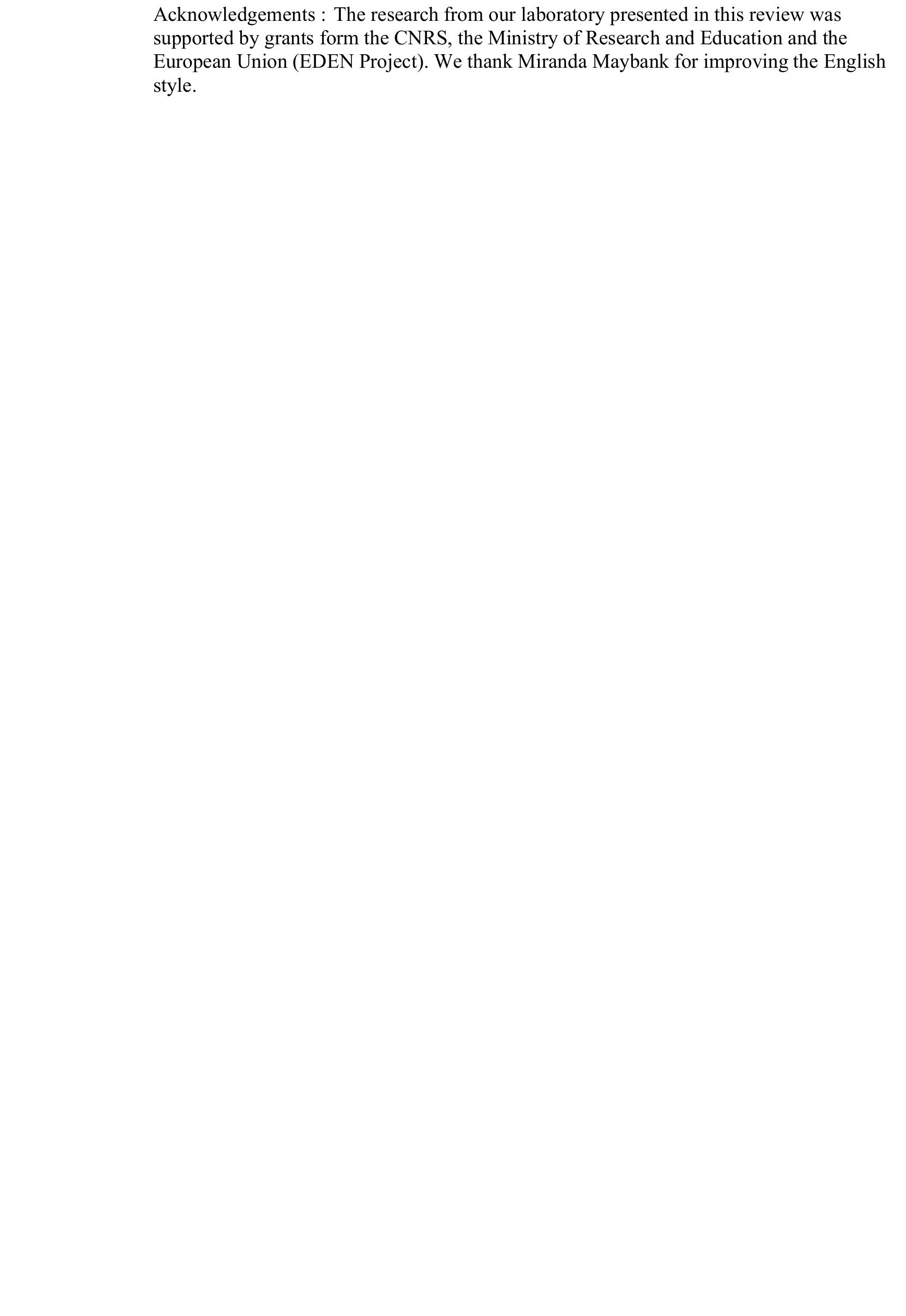

.

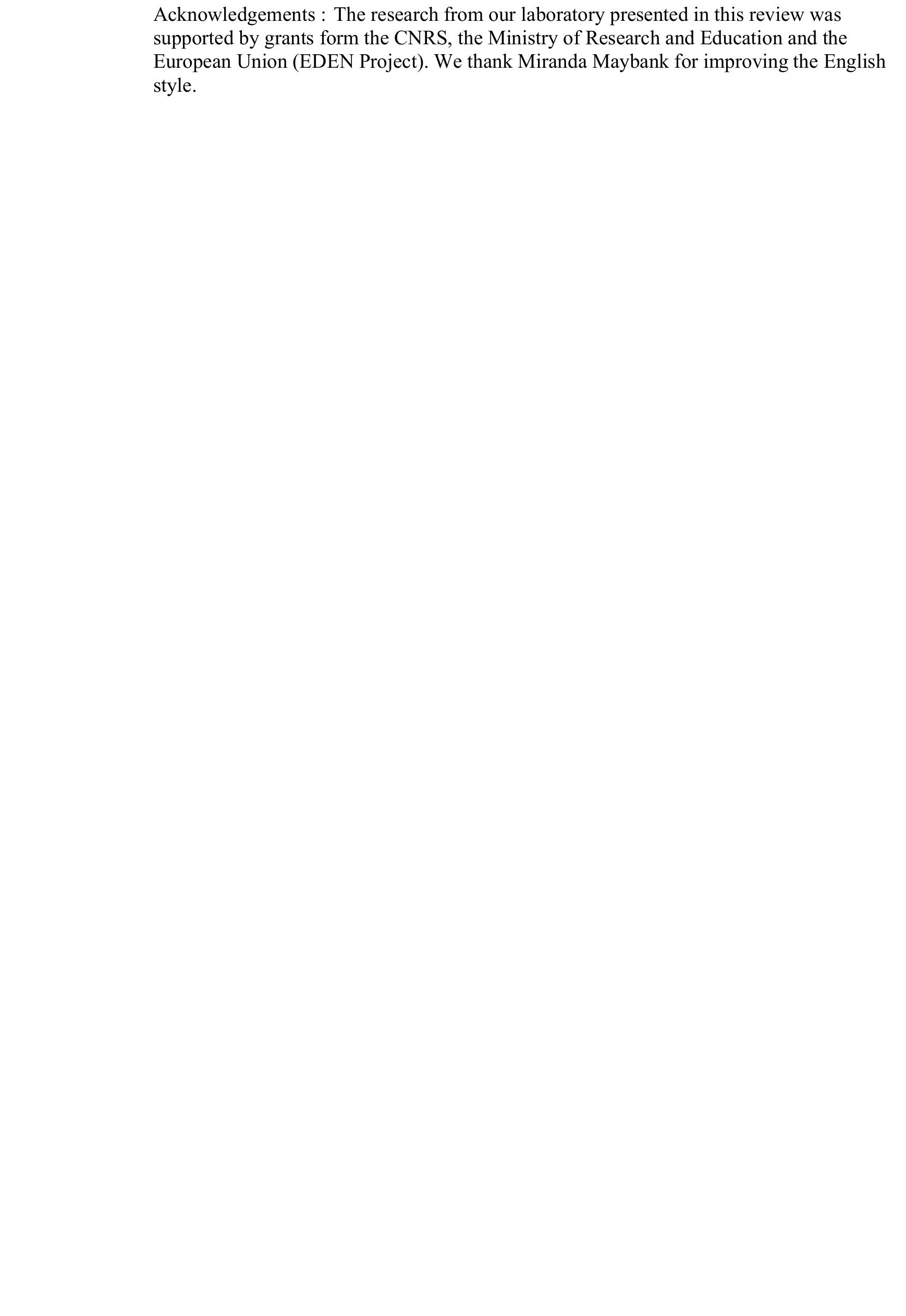

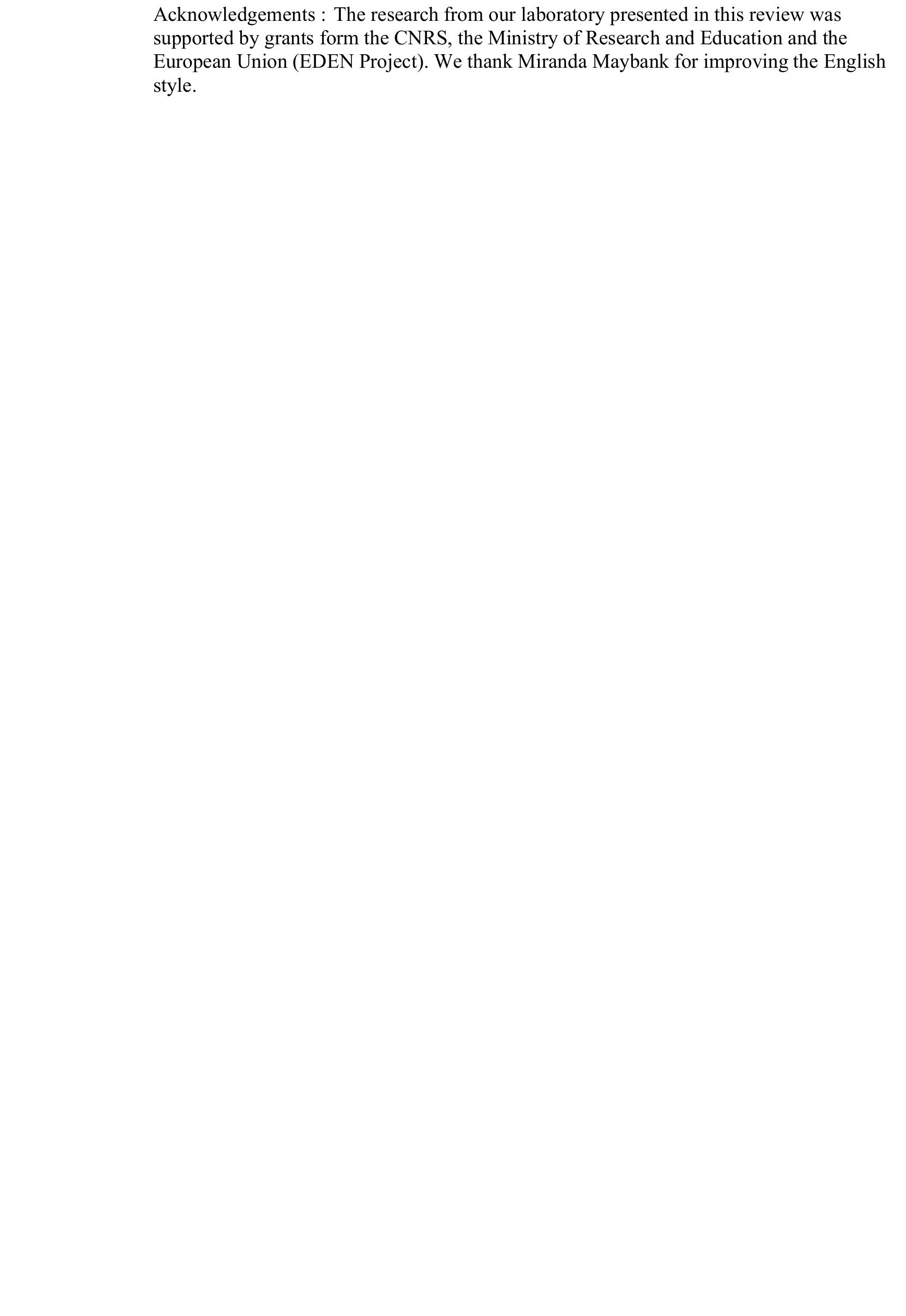

\section{Acknowledgements}

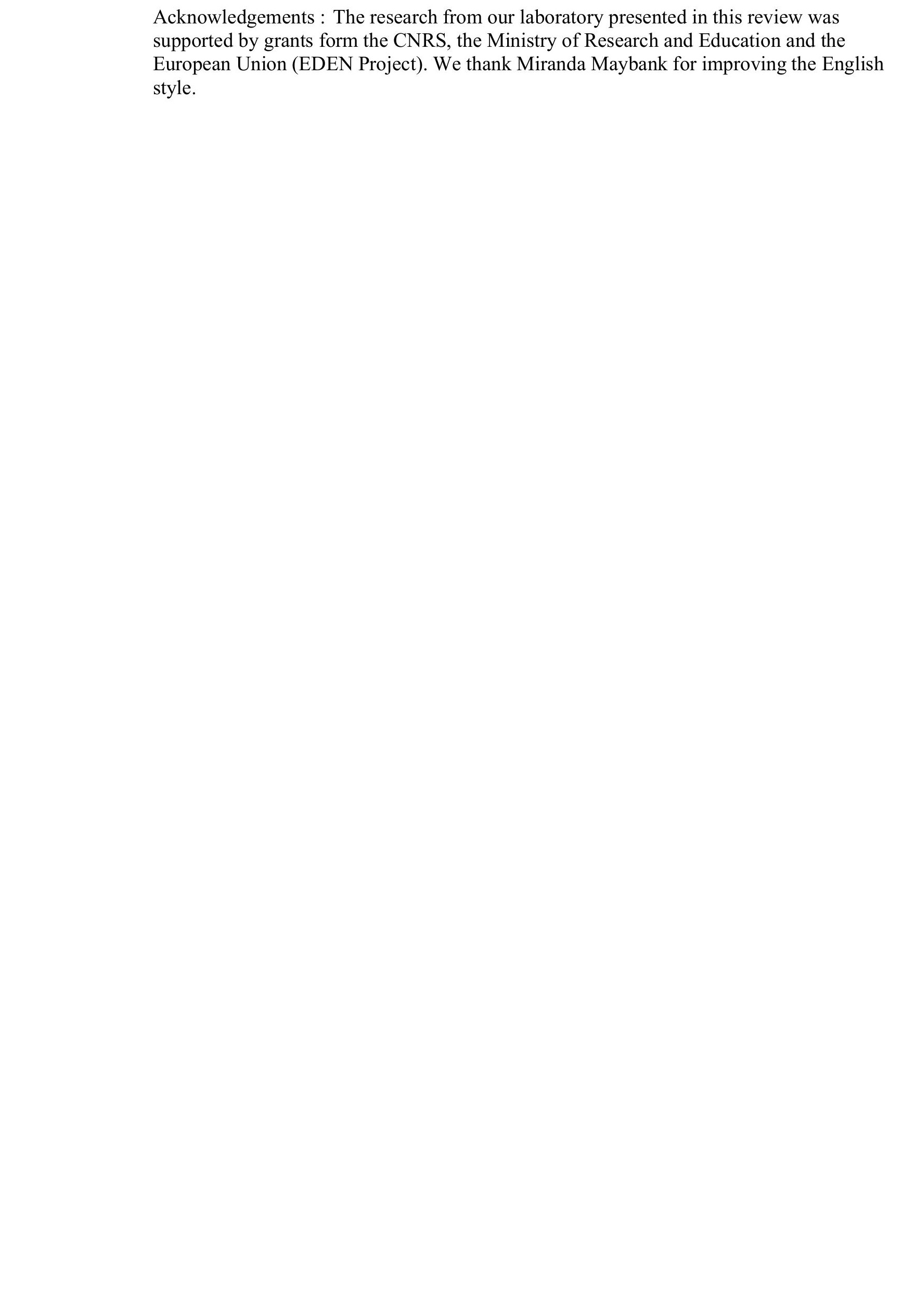

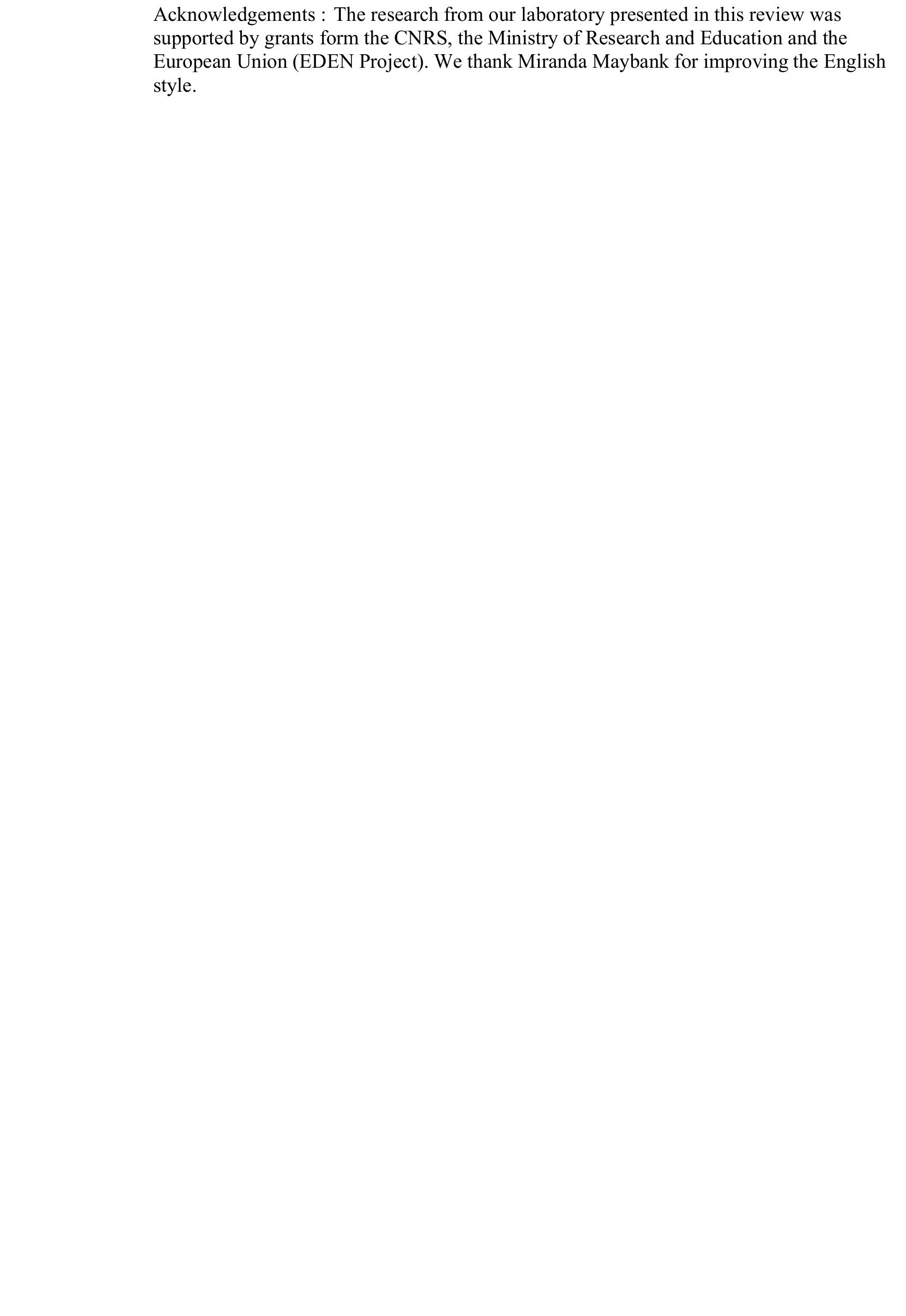

(2) 


\section{Introduction}

For a long time, it has been a prevailing dogma in neuroscience that the adult brain is unable to generate new neurons. Pioneer studies by Altman [2] or Kaplan and Hinds [31] suggesting that this assumption could be wrong, were received with scepticism or even criticism. Nowadays, it is well accepted that neurogenesis persists in discrete regions of the adult mammalian brain. However, active adult neural progenitors are restricted to two small areas of the telencephalon, the subependymal zone of the lateral ventricle (SEZ) and the subgranular zone (SGZ) of the dentate gyrus in the hippocampus [29,42]. These findings stimulated a considerable number of studies aiming at isolating neural stem cells and understanding their basic biological properties, with the ultimate objective to manipulate them and enhance repair and regeneration.

It is now established that the capacity to produce new neurons as adults is a common feature of all vertebrates and also invertebrates [41]. In non-mammalian tetrapods, neurogenesis is most documented in birds where generation of new neurons appears restricted to a single region, the periventricular zone of the lateral ventricle. This also seems to be the case in lizards [41], whereas in amphibians adult neurogenesis is poorly documented apart from the olfactory bulb and retina [41]. In contrast, there is increasing information for teleost fish, which seem to have an unparalleled capacity to produce new neurons during the adult stages.

\section{Teleost fish are the champions of adult neurogenesis}

Teleost fish represent the largest group of actinopterygian fish, a lineage that diverged some 450 millions years ago from the sarcopterygian fish, their tetrapod ancestors. Whereas there is unfortunately little data on adult neurogenesis in the basal representatives of actinopterygians, holosteans (Amia, Lepisosteus, ...) and chondrosteans (sturgeon), there is quite a lot of evidence suggesting that the adult brain of teleosts exhibits a unique capacity to 
generate new neurons. In the late 60 's, pioneer studies [34,36,37] demonstrated extensive cell proliferation in the telencephalon, diencephalon, cerebellum and spinal cord of fish. Using tritiated thymidine it was shown that, although the proliferative activity decreased progressively with age and size, the brain of the guppy still exhibited significant proliferative activity in the adult [37]. Since then, the existence of widespread periventricular proliferative zones (PZ) was confirmed in different teleost species [41]. In the stickleback, detailed comparisons of tritiated thymidine incorporation with PCNA and BrdU immunohistochemistry showed the presence of many proliferation zones in the entire brain; although the number of proliferative cells seemed to be more important in the telencephalon, diencephalon and mesencephalon [16]. This study demonstrated that all these PZ were located within or immediately below the ventricular layer, with the exception of the cerebellum in which proliferation occurred in the parenchyma. More recently, several studies further documented the presence of mitogenic zones capable of generating new neurons in many parts of the telencephalon, diencephalon, midbrain and cerebellum of zebrafish $[1,27,56,73]$. These data confirmed that adult fish exhibit an enormous potential for neurogenesis, compared to tetrapods, and that adult neurogenesis not only occurred in regions homologous to neurogenic regions in mammals, but also in many other regions throughout the entire brain. This is most likely linked to the fact that fish keep growing during their entire lifespan, making it necessary to constantly generate new neurons $[8,9]$. This, of course, suggests that in addition to the high proliferative activity, other cellular processes such as apoptosis, migration, and differentiation must occur, but these are poorly documented.

Thus, the question is: Why do fish adult stem cells maintain their mitogenic activity in many regions, whereas in other vertebrates adult neurogenesis is limited to just one or two discrete areas? Recent data in mammals indicate that a combination of intrinsic and extrinsic cues dictates the behaviour of adult neural progenitor [29,51]. In this review, we would like to 
examine the possibility that one of the mechanisms participating in the establishment of a highly permissive environment in the adult fish brain could be linked to their unique capacity to produce estrogens, because of a strong expression of the estrogen synthesizing enzyme aromatase (estrogen synthase). Indeed, apart from this exaggerated proliferative activity, another major feature of the adult fish brain is its exceptionally high aromatase activity. Despite the fact that this has been known for some time, the significance of this peculiarity is still not clearly understood $[54,55]$.

\section{Aromatase, the estrogen-synthesizing enzyme is strongly expressed in radial glial cells}

\section{of the adult fish brain.}

The terminal step of estrogen biosynthesis is catalyzed by an enzyme complex termed aromatase (estrogen synthase). This key complex, bound to the endoplasmic reticulum membrane, is formed by the cytochrome $\mathrm{P} 450$ aromatase, a heme binding protein produced by the cyp 19 gene, and by an ubiquitous flavoprotein, the NADPH cytochrome P450 reductase [40]. Aromatase is expressed in the brain of all vertebrates [7], but fish exhibit several interesting and unique features compared to mammals and birds. Firstly, it is known that the total amount of enzymatic activity of aromatase ( $\mathrm{pmol} / \mathrm{mg}$ protein) in the brain of fish is one hundred to one thousand times higher than in corresponding regions of mammals and birds $[12,54]$. Microanatomical and biochemical techniques have shown that an exceptional potential for aromatization takes place in the forebrain of fish, particularly in the telencephalon, preoptic area and the hypothalamus [67]. Secondly, teleosts possess two aromatase genes in their genome. In mammals and birds, aromatase is generated from a single cyp19 gene that is regulated by multiple tissue-specific region promoters and alternative splicing, resulting in transcript variants but identical coding sequences [11]. In most fish, there are two distinct genes, cyp19a and cyp19b, each of which is regulated differently and encodes a structurally and functionally different aromatase protein $[15,66]$. Data from a large 
sample of fish showed that the two genes have consistently different patterns of expression, CYP19A (Aromatase A) is predominantly expressed in the gonads while CYP19B (Aromatase B: AroB) is mainly expressed in the brain $[15,24,48,66]$, providing a good example of partition of function between duplicated genes[60].

In the brain of birds and mammals, aromatase was for a long time only reported in neurons, notably of the diencephalon and limbic systems [7,72]. However, more recently aromatase was described in radial cells of the developing cortex in the mouse [45] and in astrocytes of the adult human cortex [71]. In contrast, another unique characteristic of teleosts is the fact that AroB expression in adults is strictly confined to radial glial cells. Such cells are characterized by a small nucleus adjacent to the ventricle and long radial processes terminating by end feet at the brain surface [59]. Radial cells are strongly involved in embryonic neurogenesis and, in contrast to mammals where they disappear at the end of neurogenesis, they largely persist in the adult brain of non-mammals, notably in fish. Strong expression of AroB in radial glial cells of fish was first shown in the plainfin midshipman [18] and then in trout, zebrafish, pejerrey and bluehead wrasse $[44,48,50,63]$. In the trout and zebrafish we showed that both AroB mRNA and protein expression, in adult mature fish, are strictly confined to radial glial cells. These AroB-expressing cells are most abundant in the forebrain, notably in the olfactory bulbs, the telencephalon, the preoptic area and the mediobasal hypothalamus, in particular along the lateral and posterior recesses [50]. However, consistent with the distribution of the messengers [48], AroB-positive cells were also observed in the periventricular layers bordering the optic tectum, the torus semicircularis and along the fourth ventricle $[48,50]$.

That aromatase B is expressed in radial glial cells in the brain of adult teleosts is also supported by the fact that such cells were shown to express a variety of markers; in particular Brain Lipid Binding Protein (BLBP), a nervous system-specific member of the large family of 
hydrophobic ligand binding proteins, which is exclusively expressed in radial glial cells and astrocytes throughout the developing brain $[1,5,6]$. BLBP displays very high expression in radial glial cells of zebrafish [1] where it is often co-expressed with AroB (K. Mouriec and N. Diotel, unpublished data). In addition, the exclusive expression of AroB in radial glial cells was confirmed by the fact that none of these cells express markers of post-mitotic neurons such as $\mathrm{HuC} / \mathrm{D}$, a RNA-binding protein selectively expressed in neurons, or acetylated tubulin $[18,56]$.

\section{Radial glial cells are progenitor cells in adult fish}

The role of radial glial cells in embryonic neurogenesis is well established in birds and mammals. First known for serving as scaffolds for neuronal migration during embryonic neurogenesis [59], radial glial cells are now considered as progenitor cells able to generate glial cells (astrocytes, oligodendrocytes and ependymal cells) and neurons [25,26,52,53]. More recently, data showed that radial glial cells are the source of all brain neurons not only during development, but also in adults [26]. In birds, adult neurogenesis results from asymmetric division of the radial glial cells which give rise to newborn neurons migrating tangentially and radially along radial extensions to reach the telencephalon [4]. In adult mammals, astrocytes from the subventricular zone act as stem cells which divide to generate precursors ultimately generating neurons, some of which migrate to colonize olfactory bulbs [42]. Nevertheless, radial glial cells disappear after the embryogenesis in mammals $[52,53]$. In contrast, radial glial cells persist in other vertebrates, notably in birds [3] and fish $[48,59]$. However, it is only recently that the implication of radial cells in adult neurogenesis has been envisioned. Recent data in zebrafish have further confirmed the very high proliferative activity of the brain, already documented in other teleost species $[1,27,56,73]$. Using BrdU immunohistochemistry and aromatase B as a marker of radial glial cells it was found that, at short survival times (12 and 24 hours), a large majority of cells exhibiting BrdU labelling 
corresponded to AroB-positive radial cells [56]. The radial nature of proliferative cells in the telencephalon and diencephalon was also indicated using antibodies to BLBP [1]. In addition, it was shown that, over time, newborn cells clearly move away from the periventricular proliferative zones, as indicated by double BrdU/PCNA staining [1,56,73], using radial processes as scaffolds [56]. Whilst in most of the forebrain newborn cells appear to move radially, actively dividing cells from the ventral subpallium generate rapidly dividing progenitors and neuroblasts that reach the olfactory bulb via a rostral migratory stream [1]. In the zebrafish, many of the newborn cells differentiate into neurons, as shown by combining BrdU and the use of several neuronal markers such as Hu or Acetylated-Tubulin $[1,27,56,73]$ Thus, at least a subset of AroB-positive radial glial cells represents progenitor cells and is capable of actively dividing to generate new neurons. As mentioned above, aromatase is the only synthetic enzyme of estrogens; indicating that, provided aromatizable androgens are available, such cells will produce locally high amounts of estrogens that will act in a paracrine or autocrine fashion in these periventricular proliferative regions (Figure 1). Although preliminary results (K. Mouriec, unpublished data) indicate that E2 modulates cell proliferation in zebrafish, this remains to be thoroughly evaluated. However, increasing evidence suggests that estrogens may promote neurogenesis in other vertebrate models.

\section{Emerging new functions of estrogens in embryonic, adult or reparative neurogenesis}

Due to its well-documented synchronizing effects on the reproductive axis, estradiol (E2) is best know as a female sexual steroid. However, it is now considered, in both males and females, as a hormone exhibiting a myriad of neurotrophic and neuroprotective functions that are essential for neuronal development, survival and plasticity throughout life $[12,24,62]$. This variety of effects is correlated to the diversity of the cellular and molecular mechanisms underlying estrogen actions. Indeed, estrogenic effects may rely on activation of specific intracellular estrogen receptors, ER $\alpha$ and ER $\beta$. These intracellular estrogen receptors 
modulate gene expression and produce long-term genomic effects on interaction with plasma membrane sites that produce rapid non-genomic actions, and also on a growing number of receptor-independent mechanisms [69].

Estradiol is present in the brain of vertebrates from developmental stages until adulthood and is known for influencing neuronal differentiation, survival and plasticity $[10,22,64,69]$. However, a number of recent data suggest that estrogen could also influence the behaviour of progenitors and influence neurogenesis.

In rodents, it is known that brain aromatase activity is maximal during the embryonic period [40]. While aromatase was mostly believed to influence the construction of male specific structures according to the aromatization hypothesis [47], it was recently reported that aromatase is strongly expressed in radial cells of the embryonic neocortex and that such aromatase-expressing radial cells also express ER $\alpha$ [45]. Furthermore, in vitro E2 administration increased proliferation, while in utero blockade of estrogen receptors decreases proliferation of these embryonic cortical progenitor cells [45]. These data, whilst not forgetting the situation in adult fish [56], suggest a new functional role for E2 as a proliferative agent during critical stages of cerebral cortex development [45]. Such findings are in agreement with the fact that the brains of adult ER $\beta-/-$ knockout mice show regional neuronal hypocellularity, especially in the cerebral cortex [30]. While in rodents, the source of aromatizable androgens necessary for estrogen production in the cortex is not known, recent studies in songbirds (at posthatch day land 5) indicated that all the genes required for de novo estrogen synthesis from cholesterol are expressed in the developing brain of both sexes, with a spatial distribution similar to the known pattern of proliferating neuronal precursors along the lateral border of the lateral ventricle [43]. 
De novo synthesis of estrogens from cholesterol is also documented in neurogenic regions in the adult rodent, notably in the hippocampus, where the E2 concentrations can be higher than in the blood [28].

There is also rapidly accumulating data showing that estradiol modulates adult neurogenesis in the dentate gyrus of normal $[17,20,21]$ or diabetic rats $[61,62]$, a mechanism that would implicate ER $\alpha$ and ER $\beta$ [46]. Furthermore, the anatomical and functional implications of brain aromatase expression in the neurogenesis construction of vocal and auditory circuits in teleost fishes and songbirds, are also well documented [19,57].

In addition, estrogens have long been known for acting as a neuroprotective factor under brain repair situations. Until recently [45,71], aromatase expression had been reported in astrocytes (in rat) or in radial glial cells (in birds) only after chemical or mechanical lesions $[23,57,58]$. More lately, this increase in estrogen production around the lesions is correlated with increased neurogenesis as demonstrated by several recent studies $[39,70]$. Furthermore, it was shown that estradiol enhances neurogenesis following ischemic stroke through ER $\alpha$ and ER $\beta$ signalling [65].

All these data suggest that estrogens should be taken into consideration among other factors potentially regulating embryonic, adult and reparative neurogenesis. If it is clear that estrogens are locally produced in neurogenic regions, notably in the vicinity or even within progenitor cells, many questions remain open regarding the significance of these data. Open questions notably concern the regulation of brain aromatase expression and the origin, central or peripheral, of aromatizable androgenic precursors.

\section{What triggers aromatase expression in the brain of fish?}

The promoter of the zebrafish cyp $19 \mathrm{~b}$ gene has been characterized by several groups $[13,32,50,68]$. Analysis of the promoter sequence revealed the presence of a TATA box, 
several putative cis regulatory elements including an Estrogen-Responsive Element (ERE) and an half ERE and pioneer studies indicated that AroB is up-regulated by E2, its own product $[33,35]$. Of particular interest is the finding that if embryos are treated for 2,3 or 5 days with E2 $(10 \mathrm{nM})$ a very strong up-regulation of AroB messenger, protein and activity is observed exclusively in the radial glial cells of zebrafish larvae [50]. This effect is entirely blocked by an excess of the pure anti-estrogen ICI 182780 , indicating the requirement of one of the three zebrafish estrogen receptors [49]. The fact that ERs are necessary for the upregulation of AroB, but not sufficient alone, is further evidenced by the fact that ER are expressed in many cells in the brain parenchyma that do not express AroB [49].This is further indicated by in vitro studies showing that E2 up-regulation of an AroB-reporter gene in the presence of E2 was only observed in certain cell contexts, again indicating the need of specific factors. Interestingly, strong up-regulation of the zebrafish AroB-luciferase reporter in the presence of zebrafish ER was observed only in P19 cells, differentiated into neurons and glial cells by retinoic acid, or in U251-MG human astrocytes indicating that a "neuroglial" cell context is necessary $[14,38,55]$. These data correlate well with the fact that deletion/mutation of the ERE on the AroB promoter results in the total absence of E2 induction. Interestingly, deletion/mutation of a sequence upstream of the ERE, named GxrE, also prevents the E2 stimulation of the AroB-luciferase even when the ERE is intact. As shown by gel shift experiments, this sequence is able to bind nuclear extracts from P19 cells differentiated into neurons and glial cells by retinoic acid, or in U251-MG human astrocytes, but not from other cell lines [50]. These data suggest that ER could act in cooperation with some unknown neuro-glial factor to promote the up-regulation of the cyp $19 \mathrm{~b}$ gene in neuroglial or glial cells (Figure 2). So, our hypothesis is that a positive autoregulatory loop explains the high expression of Aro-B in radial glial cells of adult fish. Indeed, high circulating steroid levels will further promote AroB expression in radial cells. Whether such a mechanism is also 
implicated in expression of aromatase in other vertebrates is unknown and requires urgent investigation.

\section{Conclusions}

These data stress the originality of the teleost fish brain in which progenitor radial glial cells, and not neurons, strongly express the estrogen synthesis enzyme, aromatase. Until recently, it was thought that aromatase expression in radial cells was a unique feature of teleosts, but very recent data suggest that aromatase is expressed in radial glial cells during embryogenesis or under brain repair situations in other vertebrates. In addition, an increasing number of studies point to the role of estrogens in cell proliferation and neurogenesis. Overall, this suggests that the brain of adult fish possibly presents an exaggeration of a more general mechanism involving estrogens in embryonic, adult and reparative neurogenesis. 


\section{References}

[1] B. Adolf, P. Chapouton, C.S. Lam, S. Topp, B. Tannhaüser, U. Strahle, M. Gotz and L. Bally-Cuif, Conserved and acquired features of adult neurogenesis in the zebrafish telencephalon, Dev Biol 295 (2006) 278-293.

[2] J. Altman, Are new neurons formed in the brains of adult mammals?, Science 135 (1962) 1127-1128.

[3] A. Alvarez-Buylla, D.R. Buskirk and F. Nottebohm, Monoclonal antibody reveals radial glia in adult avian brain, J Comp Neurol 264 (1987) 159-170.

[4] A. Alvarez-Buylla, B. Seri and F. Doetsch, Identification of neural stem cells in the adult vertebrate brain, Brain Res Bull 57 (2002) 751-758.

[5] T.E. Anthony, C. Klein, G. Fishell and N. Heintz, Radial glia serve as neuronal progenitors in all regions of the central nervous system, Neuron 41 (2004) 881-890.

[6] T.E. Anthony, H.A. Mason, T. Gridley, G. Fishell and N. Heintz, Brain lipid-binding protein is a direct target of Notch signaling in radial glial cells, Genes Dev 19 (2005) 1028-1033.

[7] J. Balthazart and G.F. Ball, New insights into the regulation and function of brain estrogen synthase (aromatase), Trends Neurosci 21 (1998) 243-249.

[8] R. Brandstätter and K. Kotrschal, Brain growth patterns in four European cyprinid fish species (Cyprinidae, Teleostei): roach (Rutilus rutilus), bream (Abramis brama), common carp (Cyprinus carpio) and sabre carp (Pelecus cultratus), Brain Behav Evol 35 (1990) 195-211.

[9] R. Brandstätter and K. Kotrschal, Life history of roach, Rutilus rutilus (Cyprinidae, Teleostei). A qualitative and quantitative study on the development of sensory brain areas, Brain Behav Evol 34 (1989) 35-42.

[10] D.W. Brann, K. Dhandapani, C. Wakade, V.B. Mahesh and M.M. Khan, Neurotrophic and neuroprotective actions of estrogen: basic mechanisms and clinical implications, Steroids 72 (2007) 381-405.

[11] S.E. Bulun, K. Takayama, T. Suzuki, H. Sasano, B. Yilmaz and S. Sebastian, Organization of the human aromatase p450 (CYP19) gene, Semin Reprod Med 22 (2004) 5-9.

[12] G.V. Callard, Z. Petro and K.J. Ryan, Phylogenetic distribution of aromatase and other androgen-converting enzymes in the central nervous system, Endocrinology 103 (1978) 2283-2290.

[13] G.V. Callard, A.V. Tchoudakova, M. Kishida and E. Wood, Differential tissue distribution, developmental programming, estrogen regulation and promoter characteristics of cyp19 genes in teleost fish, J Steroid Biochem Mol Biol 79 (2001) 305-314.

[14] K. Cheshenko, F. Pakdel, H. Segner, O. Kah and R.I. Eggen, Interference of endocrine disrupting chemicals with aromatase CYP19 expression or activity, and consequences for reproduction of teleost fish, Gen Comp Endocrinol (2007).

[15] E.F. Chiang, Y.L. Yan, S.K. Tong, P.H. Hsiao, Y. Guiguen, J. Postlethwait and B.C. Chung, Characterization of duplicated zebrafish cyp19 genes, J Exp Zool 290 (2001) 709-714.

[16] P. Ekström, C.M. Johnsson and L.M. Ohlin, Ventricular proliferation zones in the brain of an adult teleost fish and their relation to neuromeres and migration (secondary matrix) zones, J Comp Neurol 436 (2001) 92-110.

[17] L. Fester, V. Ribeiro-Gouveia, J. Prange-Kiel, C. von Schassen, M. Bottner, H. Jarry and G.M. Rune, Proliferation and apoptosis of hippocampal granule cells require local oestrogen synthesis, J Neurochem 97 (2006) 1136-1144. 
[18] P.M. Forlano, D.L. Deitcher, D.A. Myers and A.H. Bass, Anatomical distribution and cellular basis for high levels of aromatase activity in the brain of teleost fish: aromatase enzyme and mRNA expression identify glia as source, J Neurosci 21 (2001) 8943-8955.

[19] P.M. Forlano, B.A. Schlinger and A.H. Bass, Brain aromatase: new lessons from nonmammalian model systems, Front Neuroendocrinol 27 (2006) 247-274.

[20] C.D. Fowler, F. Johnson and Z. Wang, Estrogen regulation of cell proliferation and distribution of estrogen receptor-alpha in the brains of adult female prairie and meadow voles, J Comp Neurol 489 (2005) 166-179.

[21] L.A. Galea, M.D. Spritzer, J.M. Barker and J.L. Pawluski, Gonadal hormone modulation of hippocampal neurogenesis in the adult, Hippocampus 16 (2006) 225232.

[22] L.M. Garcia-Segura, I. Azcoitia and L.L. DonCarlos, Neuroprotection by estradiol, Prog Neurobiol 63 (2001) 29-60.

[23] L.M. Garcia-Segura, S. Veiga, A. Sierra, R.C. Melcangi and I. Azcoitia, Aromatase: a neuroprotective enzyme, Prog Neurobiol 71 (2003) 31-41.

[24] A. Gonzalez and F. Piferrer, Characterization of aromatase activity in the sea bass: effects of temperature and different catalytic properties of brain and ovarian homogenates and microsomes, J Exp Zool 293 (2002) 500-510.

[25] M. Götz, Glial cells generate neurons--master control within CNS regions: developmental perspectives on neural stem cells, Neuroscientist 9 (2003) 379-397.

[26] M. Götz and Y.A. Barde, Radial glial cells defined and major intermediates between embryonic stem cells and CNS neurons, Neuron 46 (2005) 369-372.

[27] H. Grandel, J. Kaslin, J. Ganz, I. Wenzel and M. Brand, Neural stem cells and neurogenesis in the adult zebrafish brain: Origin, proliferation dynamics, migration and cell fate, Dev Biol 295 (2006) 263-277.

[28] Y. Hojo, T.A. Hattori, T. Enami, A. Furukawa, K. Suzuki, H.T. Ishii, H. Mukai, J.H. Morrison, W.G. Janssen, S. Kominami, N. Harada, T. Kimoto and S. Kawato, Adult male rat hippocampus synthesizes estradiol from pregnenolone by cytochromes P45017alpha and P450 aromatase localized in neurons, Proc Natl Acad Sci U S A 101 (2004) 865-870.

[29] R. Jagasia, H. Song, F.H. Gage and D.C. Lie, New regulators in adult neurogenesis and their potential role for repair, Trends Mol Med 12 (2006) 400-405.

[30] K. Jin, X. Wang, L. Xie, X.O. Mao, W. Zhu, Y. Wang, J. Shen, Y. Mao, S. Banwait and D.A. Greenberg, Evidence for stroke-induced neurogenesis in the human brain, Proc Natl Acad Sci U S A 103 (2006) 13198-13202.

[31] M.S. Kaplan and J.W. Hinds, Neurogenesis in the adult rat: electron microscopic analysis of light radioautographs, Science 197 (1977) 1092-1094.

[32] Y. Kazeto, S. Ijiri, A.R. Place, Y. Zohar and J.M. Trant, The 5'-flanking regions of CYP19A1 and CYP19A2 in zebrafish, Biochem Biophys Res Commun 288 (2001) 503-508.

[33] Y. Kazeto, A.R. Place and J.M. Trant, Effects of endocrine disrupting chemicals on the expression of CYP19 genes in zebrafish (Danio rerio) juveniles, Aquat Toxicol 69 (2004) 25-34.

[34] W. Kirsche, [On postembryonic matrix zones in the brain of various vertebrates and their relationship to the study of the brain structure], Z Mikrosk Anat Forsch 77 (1967) 313-406.

[35] M. Kishida, M. McLellan, J.A. Miranda and G.V. Callard, Estrogen and xenoestrogens upregulate the brain aromatase isoform $(\mathrm{P} 450$ aromB $)$ and perturb 
markers of early development in zebrafish (Danio rerio), Comp Biochem Physiol B Biochem Mol Biol 129 (2001) 261-268.

[36] D. Kranz and W. Richter, [Autoradiographic studies on the localization of the matrix zones of the diencephalon of young and adult Lebistes reticulatus (Teleostae)], Z Mikrosk Anat Forsch 82 (1970) 42-66.

[37] D. Kranz and W. Richter, [Autoradiographic studies on the synthesis of DNA in the cerebellum and medulla oblongata of teleosts of various ages], Z Mikrosk Anat Forsch 82 (1970) 264-292.

[38] Y. Le Page, M. Scholze, O. Kah and F. Pakdel, Assessment of xenoestrogens using three distinct estrogen receptors and the zebrafish brain aromatase gene in a highly responsive glial cell system, Environ Health Perspect 114 (2006) 752-758.

[39] R.R. Leker, F. Soldner, I. Velasco, D.K. Gavin, A. Androutsellis-Theotokis and R.D. McKay, Long-lasting regeneration after ischemia in the cerebral cortex, Stroke 38 (2007) 153-161.

[40] E.D. Lephart, A review of brain aromatase cytochrome P450, Brain Res Brain Res Rev 22 (1996) 1-26.

[41] B.W. Lindsey and V. Tropepe, A comparative framework for understanding the biological principles of adult neurogenesis, Prog Neurobiol 80 (2006) 281-307.

[42] P.M. Lledo, M. Alonso and M.S. Grubb, Adult neurogenesis and functional plasticity in neuronal circuits, Nat Rev Neurosci 7 (2006) 179-193.

[43] S.E. London and B.A. Schlinger, Steroidogenic enzymes along the ventricular proliferative zone in the developing songbird brain, J Comp Neurol 502 (2007) 507521.

[44] K.E. Marsh, L.M. Creutz, M.B. Hawkins and J. Godwin, Aromatase immunoreactivity in the bluehead wrasse brain, Thalassoma bifasciatum: immunolocalization and coregionalization with arginine vasotocin and tyrosine hydroxylase, Brain Res 1126 (2006) 91-101.

[45] V. Martinez-Cerdeno, S.C. Noctor and A.R. Kriegstein, Estradiol stimulates progenitor cell division in the ventricular and subventricular zones of the embryonic neocortex, Eur J Neurosci 24 (2006) 3475-3488.

[46] C.A. Mazzucco, S.E. Lieblich, B.I. Bingham, M.A. Williamson, V. Viau and L.A. Galea, Both estrogen receptor alpha and estrogen receptor beta agonists enhance cell proliferation in the dentate gyrus of adult female rats, Neuroscience 141 (2006) 17931800 .

[47] M.M. McCarthy, Molecular aspects of sexual differentiation of the rodent brain, Psychoneuroendocrinology 19 (1994) 415-427.

[48] A. Menuet, I. Anglade, R. Le Guevel, E. Pellegrini, F. Pakdel and O. Kah, Distribution of aromatase mRNA and protein in the brain and pituitary of female rainbow trout: Comparison with estrogen receptor alpha, J Comp Neurol 462 (2003) 180-193.

[49] A. Menuet, E. Pellegrini, I. Anglade, O. Blaise, V. Laudet, O. Kah and F. Pakdel, Molecular characterization of three estrogen receptor forms in zebrafish: binding characteristics, transactivation properties, and tissue distributions, Biol Reprod 66 (2002) 1881-1892.

[50] A. Menuet, E. Pellegrini, F. Brion, M.M. Gueguen, I. Anglade, F. Pakdel and O. Kah, Expression and estrogen-dependent regulation of the zebrafish brain aromatase gene, $\mathrm{J}$ Comp Neurol 485 (2005) 304-320.

[51] J. Ninkovic and M. Götz, Signaling in adult neurogenesis: from stem cell niche to neuronal networks, Curr Opin Neurobiol (2007).

[52] S.C. Noctor, A.C. Flint, T.A. Weissman, W.S. Wong, B.K. Clinton and A.R. Kriegstein, Dividing precursor cells of the embryonic cortical ventricular zone have 
morphological and molecular characteristics of radial glia, J Neurosci 22 (2002) 31613173.

[53] S.C. Noctor, V. Martinez-Cerdeno, L. Ivic and A.R. Kriegstein, Cortical neurons arise in symmetric and asymmetric division zones and migrate through specific phases, Nat Neurosci 7 (2004) 136-144.

[54] M. Pasmanik and G.V. Callard, Aromatase and 5 alpha-reductase in the teleost brain, spinal cord, and pituitary gland, Gen Comp Endocrinol 60 (1985) 244-251.

[55] E. Pellegrini, A. Menuet, C. Lethimonier, F. Adrio, M.M. Gueguen, C. Tascon, I. Anglade, F. Pakdel and O. Kah, Relationships between aromatase and estrogen receptors in the brain of teleost fish, Gen Comp Endocrinol 142 (2005) 60-66.

[56] E. Pellegrini, K. Mouriec, I. Anglade, A. Menuet, Y. Le Page, M.M. Gueguen, M.H. Marmignon, F. Brion, F. Pakdel and O. Kah, Identification of aromatase-positive radial glial cells as progenitor cells in the ventricular layer of the forebrain in zebrafish, J Comp Neurol 501 (2007) 150-167.

[57] R.S. Peterson, D.W. Lee, G. Fernando and B.A. Schlinger, Radial glia express aromatase in the injured zebra finch brain, J Comp Neurol 475 (2004) 261-269.

[58] R.S. Peterson, C.J. Saldanha and B.A. Schlinger, Rapid upregulation of aromatase mRNA and protein following neural injury in the zebra finch (Taeniopygia guttata), $\mathrm{J}$ Neuroendocrinol 13 (2001) 317-323.

[59] P. Rakic, Neuronal migration and contact guidance in the primate telencephalon, Postgrad Med J 54 Suppl 1 (1978) 25-40.

[60] S. Rastogi and D.A. Liberles, Subfunctionalization of duplicated genes as a transition state to neofunctionalization, BMC Evol Biol 5 (2005) 28.

[61] F. Saravia, Y. Revsin, V. Lux-Lantos, J. Beauquis, F. Homo-Delarche and A.F. De Nicola, Oestradiol restores cell proliferation in dentate gyrus and subventricular zone of streptozotocin-diabetic mice, J Neuroendocrinol 16 (2004) 704-710.

[62] F.E. Saravia, J. Beauquis, Y. Revsin, F. Homo-Delarche, E.R. de Kloet and A.F. De Nicola, Hippocampal neuropathology of diabetes mellitus is relieved by estrogen treatment, Cell Mol Neurobiol 26 (2006) 943-957.

[63] P.H. Strobl-Mazzulla, N.P. Moncaut, G.C. Lopez, L.A. Miranda, A.V. Canario and G.M. Somoza, Brain aromatase from pejerrey fish (Odontesthes bonariensis): cDNA cloning, tissue expression, and immunohistochemical localization, Gen Comp Endocrinol 143 (2005) 21-32.

[64] S. Suzuki, C.M. Brown and P.M. Wise, Mechanisms of neuroprotection by estrogen, Endocrine 29 (2006) 209-215.

[65] S. Suzuki, L.M. Gerhold, M. Bottner, S.W. Rau, C. Dela Cruz, E. Yang, H. Zhu, J. $\mathrm{Yu}$, A.B. Cashion, M.S. Kindy, I. Merchenthaler, F.H. Gage and P.M. Wise, Estradiol enhances neurogenesis following ischemic stroke through estrogen receptors alpha and beta, J Comp Neurol 500 (2007) 1064-1075.

[66] A. Tchoudakova and G.V. Callard, Identification of multiple CYP19 genes encoding different cytochrome P450 aromatase isozymes in brain and ovary, Endocrinology 139 (1998) 2179-2189.

[67] R.J. Timmers, J.G. Lambert, J. Peute, H.G. Vullings and P.G. van Oordt, Localization of aromatase in the brain of the male African catfish, Clarias gariepinus (Burchell), by microdissection and biochemical identification, J Comp Neurol 258 (1987) 368-377.

[68] S.K. Tong and B.C. Chung, Analysis of zebrafish cyp19 promoters, J Steroid Biochem Mol Biol 86 (2003) 381-386.

[69] C.D. Toran-Allerand, Minireview: A plethora of estrogen receptors in the brain: where will it end?, Endocrinology 145 (2004) 1069-1074. 
[70] C. Wiltrout, B. Lang, Y. Yan, R.J. Dempsey and R. Vemuganti, Repairing brain after stroke: A review on post-ischemic neurogenesis, Neurochem Int (2007).

[71] J.G. Yague, A. Munoz, P. de Monasterio-Schrader, J. Defelipe, L.M. Garcia-Segura and I. Azcoitia, Aromatase expression in the human temporal cortex, Neuroscience 138 (2006) 389-401.

[72] C. Zhao, R. Fujinaga, M. Tanaka, A. Yanai, K. Nakahama and K. Shinoda, Regionspecific expression and sex-steroidal regulation on aromatase and its mRNA in the male rat brain: immunohistochemical and in situ hybridization analyses, J Comp Neurol 500 (2007) 557-573.

[73] G.K. Zupanc, K. Hinsch and F.H. Gage, Proliferation, migration, neuronal differentiation, and long-term survival of new cells in the adult zebrafish brain, $\mathrm{J}$ Comp Neurol 488 (2005) 290-319. 


\section{Legends to figure:}

Figure 1: Schematic representation of the current hypothesis regarding the role of radial glial cells in adult neurogenesis in fish. Radial glial cells divide by asymmetric division and give birth to new cells (1). Such newborn cells can occasionally further divide (2) or migrate along the long radial processes (3) to give birth to neurons (4). It is also possible that newborn cells undergo apoptosis (5). A large number of in vivo and in vitro data have demonstrated that estradiol has the capacity of modulating all these cellular activities.

Figure 2: Schematic representation of the current hypothesis for the strong aromatase B expression in the radial cells of fish. A mandatory cooperation between estrogen receptor and a « glial »-specific factor (Gx), binding onto a GxRE sequence upstream the ERE, results in a high sensitivity of the $c y p 19 b$ gene to E2. This hypothesis also explains why testosterone (T) also up-regulates aromatase B expression. 
Figure(s)

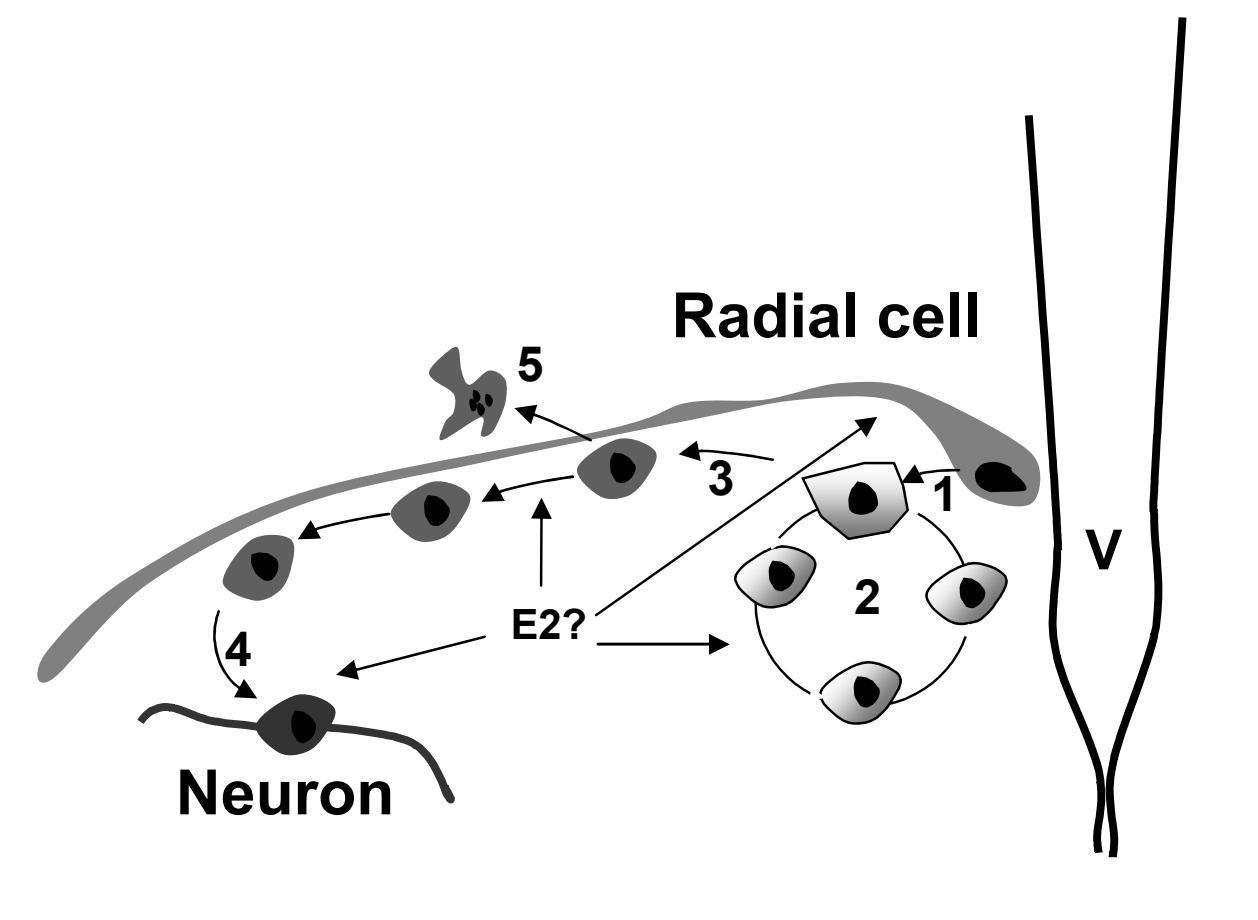

Figure 1

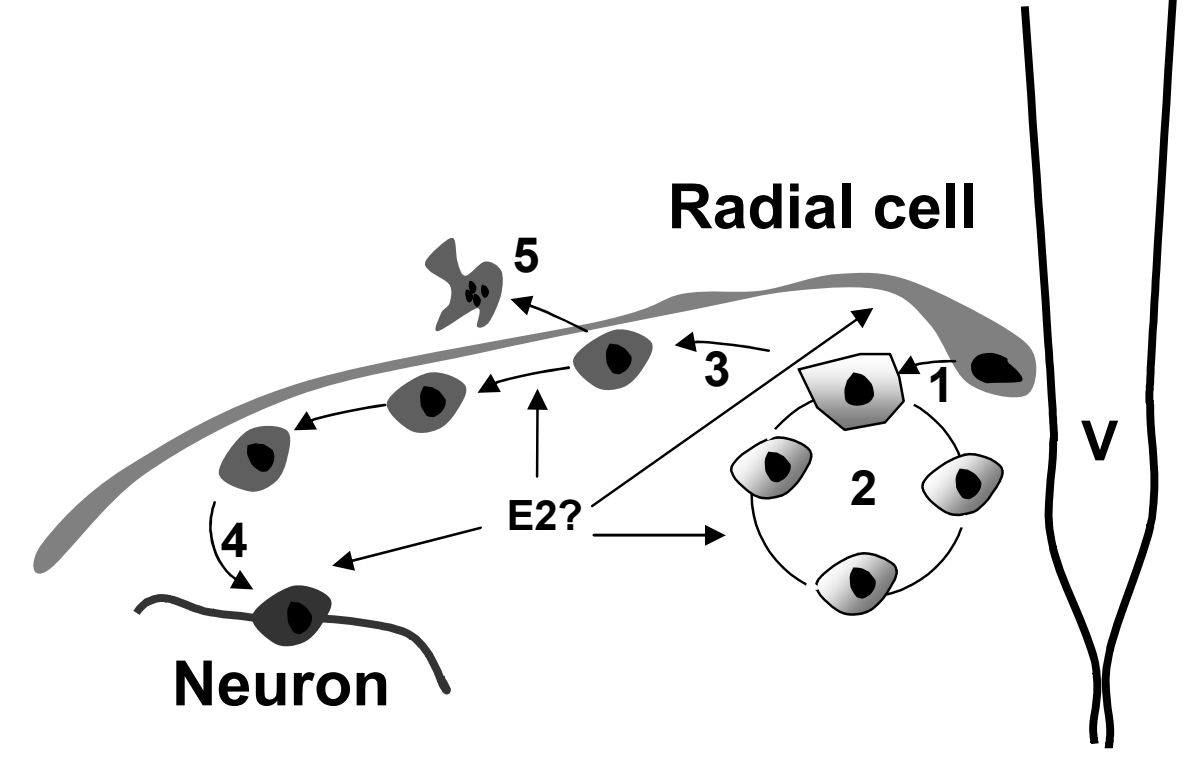
(

gure(s)

(n)

(

(

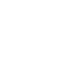

(20)

(n)
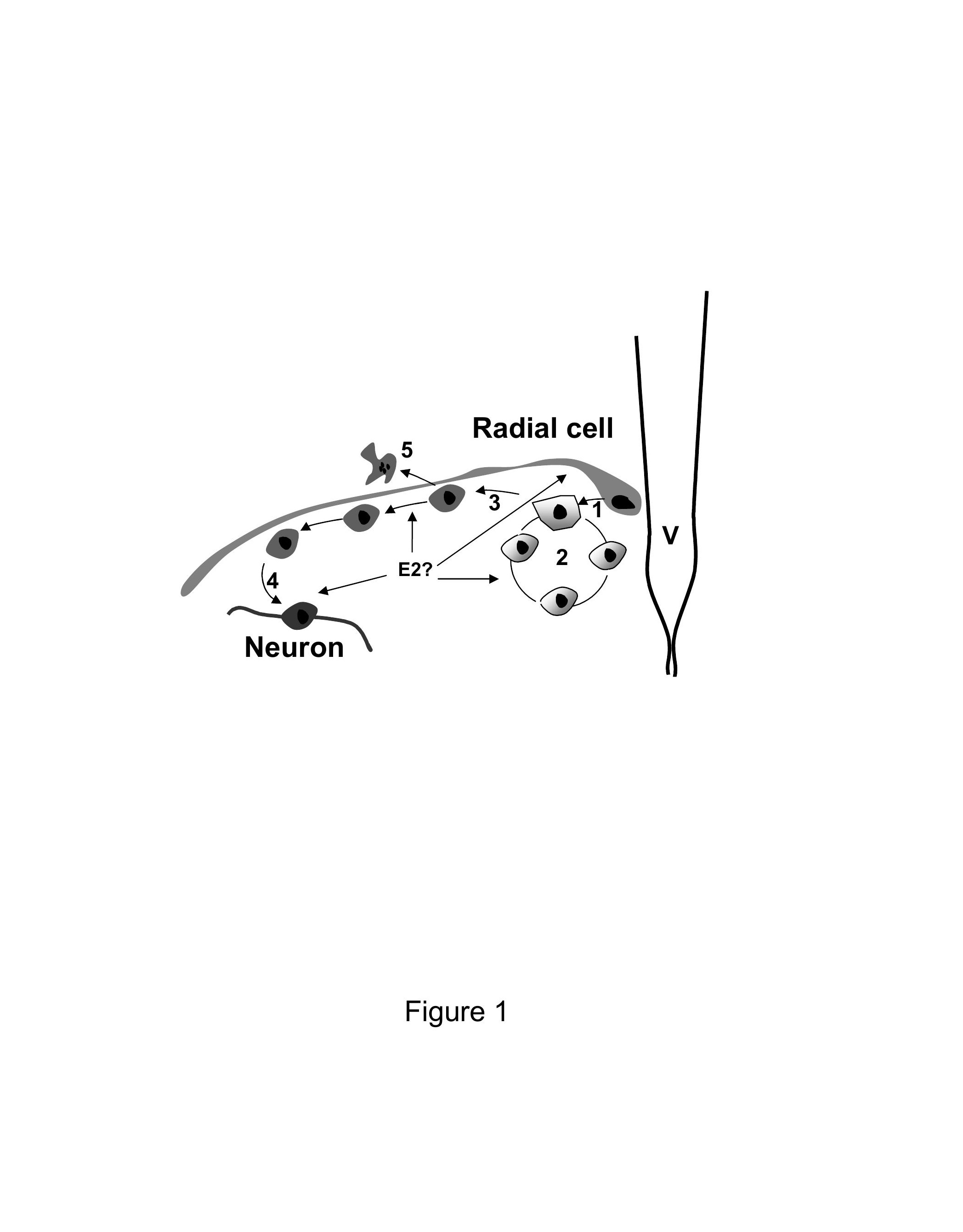


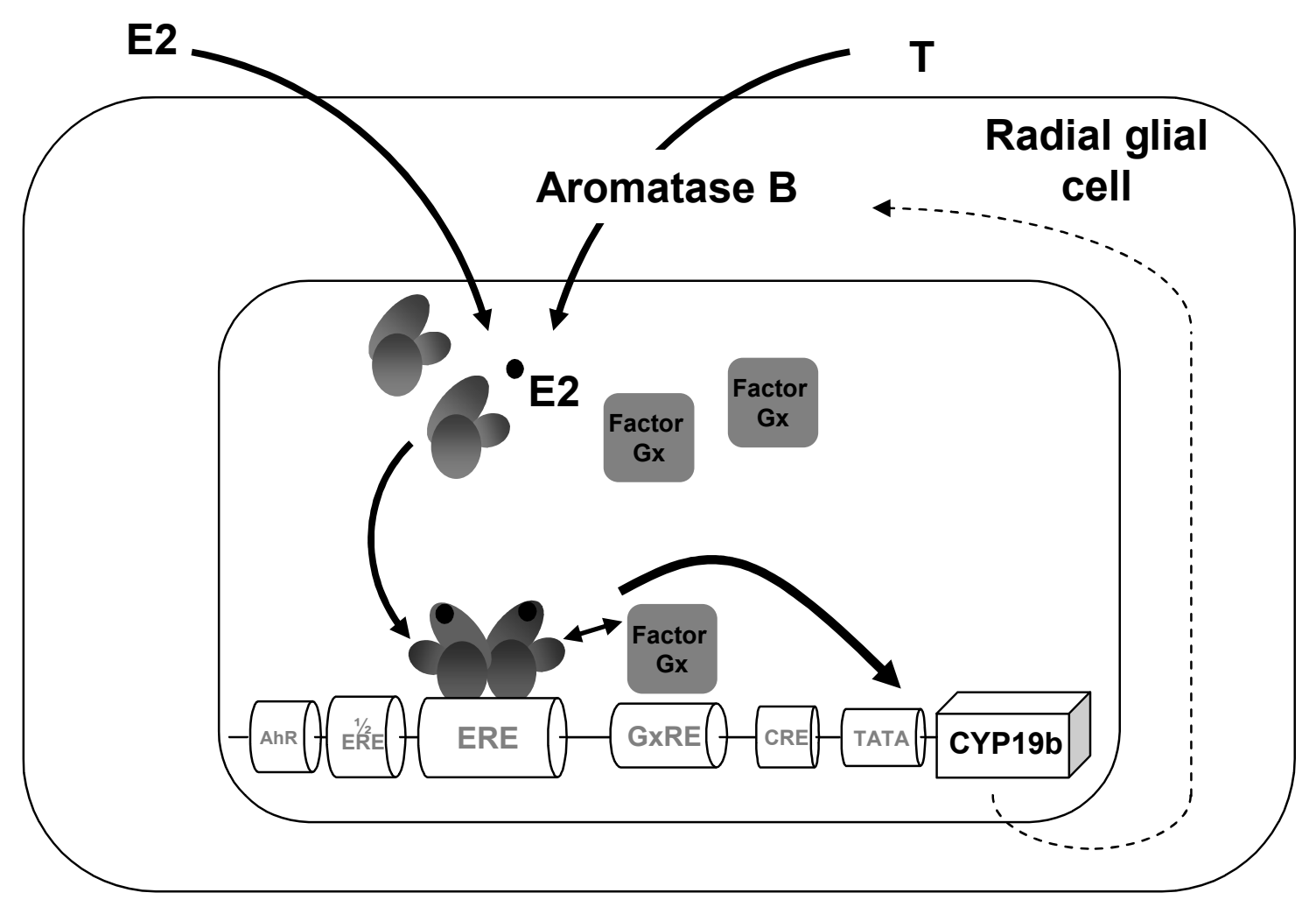

Figure 2 